\title{
Peran Financial Technology pada UMKM: Peningkatan Literasi Keuangan Berbasis Payment Gateway
}

\author{
Ayu Putu Yulia Kusuma Wardani*, Nyoman Ari Surya Darmawan \\ Universitas Pendidikan Ganesha, Singaraja, Bali, Indonesia \\ *wardani391@gmail.com
}

Riwayat Artikel:

Tanggal diajukan:

27 Juni 2020

Tanggal diterima:

29 Agustus 2020

Tanggal dipublikasi:

31 Agustus 2020

Kata kunci: Peran, Financial Technology, Literasi Keuangan

\begin{abstract}
Abstrak
Penelitian ini bertujuan untuk memahami peran financial technology pada UMKM Kecamatan Buleleng dalam peningkatan literasi keuangan berbasis payment gateway. Metode penelitian kualitatif adalah metode penelitian yang digunakan dengan jenis pendekatan deskriptif. Penelitian ini menggunakan data primer serta data sekunder yang berupa wawancara, observasi, dokumentasi. Hasil penelitian yang diperoleh adalah peran penerapan dari financial technology dapat meningkatkan literasi keuangan dengan memberikan kemudahan bagi pelaku UMKM dalam mengelola serta memahami keuangan mereka karena teknologi ini memberikan kemudahan dalam pembayaran secara digital yang secara otomatis memberikan pencatatan dalam pemasukan transaksi yang terjadi.
\end{abstract}

\section{Pengutipan:}

Wardani, A. P. Y. K., \& Darmawan, N. A. S. (2020). Peran Financial Technology pada UMKM: Peningkatan Literasi Keuangan Berbasis Payment Gateway. Jurnal IImiah Akuntansi dan Humanika, 10(2), 170-175

Keywords: Role, Financial literacy, financial technology

\begin{abstract}
The purpose of this studi was to understand the financial techology in Micro Small and Medium Entreprises in Buleleng Regency, especially in increased financial literacy based on payment gateway. This research used qualitative approach with the type of descriptive approach and also used primary data and secondary data in the form of interviews observations and documentations. The result showing that the role of financial technology could increase financial literacy and made it easier for Micro Small and Medium Entrepreneurs to manage and understans their finances because the technology provided convenience in digital payments. Therefore, it automatically recorded the income of transsaction that occur.
\end{abstract}

\section{Pendahuluan}

Perkembangan teknologi masa kini bukan lagi hal yang dianggap asing oleh masyarakat di Indonesia. Perkembangan teknologi yang terjadi saat ini mengalami perkembangan yang pesat yang akan memberikan kemudahan dalam mengakses suatu informasi serta kemudahan dalam mengelola sumber dayanya secara efektif dan efisien. Perkembangan teknologi dalam hal penggunaan internet merupakan perkembangan yang paling diminati oleh sebagian besar masyarakat. Berdasarkan data dari Asosiasi Penyelenggara Jasa Internet Indonesia (APJII) menyatakan bahwa sebesar 64,8 persen dari pemakaian internet mengalami kenaikan pada tahun 2019. Naik 10,12 persen dari 2018 yang masih di angka 54,68 persen.

Perkembangan internet yang pesat telah melahirkan inovasi-inovasi khususnya dalam teknologi finansial yang akan memenuhi kebutuhan masyarakat baik itu dalam pemberian akses layanan finansial serta pemrosesan transaksi (Rahma, 2018). Penetrasi penggunaan internet merupakan hal yang mendasari dalam perkembangan tren ekenomi yang terjadi. Pertumbuhan internet menciptakan jaringan bagi usaha usaha mikro, kecil dan 
menengah yang secara tidak langsung menjadi pondasi dalam dalam perekonomian (Martawardaya, 2016). Kontribusi yang diberikan terhadap produk domestik bruto dari sektor usaha mikro, kecil, dan menengah (UMKM) diperkirakan tumbuh sebesar $5 \%$ pada tahun 2019. Kontribusi yang diberikan terhadap produk domestik bruto (PDB) dari sektor UMKM pada tahun ini telah mencapai $65 \%$. Melihat hal itu bahwa UMKM menjadi pelaku terbesar dalam kegiatan ekonomi kita. (Syarizka, 2019)

Perubahan kebiasaan pada kegiatan ekonomi yang pada prosesnya rumit dan panjang dijadikan menjadi lebih cepat dan efisien juga disebut sebagai fenomena disruptive technology. Inovasi-inovasi dalam teknologi baik produk dan jasa. Perubahan ini merupakan perubahan yang menjadikan hal lebih sederhana, tidak membutuhkan biaya yang banyak serta penggunaan yang mudah. (Handinata, 2013). Disruptive technology dapat meciptakan peluang pasar yang lebih luas dan dapat membatu pelaku usaha dalam penyesuaian diri dengan cepat (Martawardaya, 2016).

Perkembangan dalam hal teknologi keuangan yang terjadi akan memberi pengaruh besar bagi masyarakat dalam hal bertransaksi tanpa uang tunai (Astarina, 2018). Perubahan gaya bertransaksi masyarakat ini disebut sebagai fenomena cashless society. Walaupun sebagian besar masyarakat masih memakai transaksi uang tunai tapi sebagian masyarajat mulai membiasakan untuk menggunakan non-tunai. Istilah cashless society merupakan keadaan yang menunjukan bahwa masyarakat saat ini memilih memakai uang elektronik daripada uang fisik (Rif'ah, 2019). Terjadinya fenomena cashless society ini merupakan salah satu dari peran dari financial technology (Astarina, 2019).

Layanan fintech telah menyasar kaum millenial yang memang sering menggunakan internet. Berdasarkan data Asosiasi Penyelenggara Jasa Internet Indonesia (APJII) ada 143,26 juta pengguna Internet di Indonesia, dan 49,52\% dari pengguna internet itu adalah generasi millenial. Bagi generasi milenial, sudah menjadi hal yang biasa berbelanja atau bertransaksi tanpa uang tunai. Mereka sudah terbiasa menggunakan alat-alat elektronik seperti kartu debit, kredit, ataupun uang elektronik. Perkembangan ini dan juga kemudahan dalam memakai telepon pintar dapat memberikan kemudahan dalam bertransaksi finansial. Untuk menghindari resiko dari kemudahan tersebut seperti resiko penipuan, kejahatan, dan kecurangan dalam fintech, maka pemerintah diperlukan agar nantinya dapat berupaya membantu memaksimalkan transaksi non-tunai ini bisa diterapkan secara aman dengan mendukung literasi keuangan masyarakat (Oloan, 2019).

Teknologi yang berkembang pesat dalam sektor keuangan menyebabkan banyak start up perusahaan yang bergerak di bidang financial technology. Financial technology sendiri diartikan sebagai layanan keuangan secara digital yang menyediakan layanan dalam sistem pembayaran, layanan perbankan, layanan asuransi, pinjaman, urun dana, hingga sekedar pembelajaran kepada masyarakat melalui media digital. Secara umum, layanan fintech yang berkembang saat ini di Indonesia yaitu dibagi menjadi beberapa bagian yaitu payment channel/system, digital banking, online/digital insurance, Peer-to-Peer (P2P) Lending, dan crowdfunding (Siregar, 2016)

Layanan financial technology seperti penggunaan payment channel merupakan layanan fintech yang sering digunakan oleh beberapa pelaku UMKM di Kecamatan Buleleng yang memberikan layanan elektronik sebagai alat pembayaran, sistem ini juga secara otomatis akan memberikan kemudahan dalam pengecekan pembayaran yang terjadi pada transaksi-transaksi jual beli pada pelaku UMKM. Layanan perbankan juga dimanfaatkan pelaku UMKM seperti ATM, internet banking, mobile banking yang memudahkan kegiatan transaksi untuk pembeli. Selain itu pelaku UMKM menggunakan layanan fintech sebagai sarana pembayaran tagihan, dalam pembayaran kredit serta dalam melakukan pembayaran upah/gaji karyawannya secara online. Dengan hal ini dapat memberikan kemudahan bagi pemilik bisnis dalam hal transfer ataupun penerimaan uang dengan memanfaatkan teknologi yang berkembang saat ini.

Semakin berkembangnya penggunaan uang elektronik dan pembayaran digital saat ini, membuat UMKM harus menyesuaikan diri dengan kemajuan teknologi (Dina, 2017). Usaha yang sudah berdiri lebih dari puluhan tahun yang tidak cepat tanggap mengadopsi teknologi secara pelan-pelan akan mengalami penurunan dan tertinggal dengan perusahaan 
baru yang memiliki teknologi lebih maju (Wibowo, 2017). Pelaku UMKM yang menerapkan pembayaran elektronik yang dikarenakan permintaan konsumen. Tingginya pengguna payment gateway di masyarakat membuat pelaku usaha sadar kalau mereka harus menerapkannya pada bisinis usaha. Jika tidak, bukan tidak mungkin kalau mereka akan tertinggal dan terancam punah. Selain itu, pelaku usaha juga bisa mendapatkan konsumen lebih banyak tanpa perlu melakukan promosi, mengurangi ongkos operasional, dan berpeluang untuk mendapatkan pemasukan yang lebih tinggi.

Tujuan dilakukannya penelitian ini untuk memahami peran financial technology pada UMKM di Kecamatan Buleleng dalam peningkatan literasi keuangan berbasis payment gateway.

\section{Metode}

Penelitian ini menggunakan metode kualitatif deskriptif merupakan metode yang digunakan dalam penelitian, metode ini dipilih oleh peneliti karena metode ini dilakukaan saat meneliti suatu objek alamiah yang dimana peneliti sebagai instrumen utama (Sugiyono, 2016). Pendekatan kualitatif dengan metode deskriptif dipilih karena penelitian yang dilakukan akan berfokus terhadap pengaruh dari penerapan fintech oleh UMKM untuk meningkatkan literasi keuangan

Sumber data pada penelitian ini digunakan yaitu dua sumber data: Data primer yang digunakan adalah data dari observasi dan wawancara yang secara langsung dapat diambil dari lapangan melalui pihak-pihak informan yang berkaitan dalam penelitian ini. Data sekunder yang digunakan berasal dari beberapa artikel yang terkait mengenai permasalahan yang sama, dan sumber-sumber lain seperti buku yang terkait, dan internet.

Metode pengumpulan data yang digunakan adalah observasi, wawancara, dokumentasi.

Teknik analisis data kualitatif yang digunakan yaitu pengumpulan data melalui wawancara, observasi dan studi dokumentasi lalu mereduksi data dan menyajikan data serta dapat ditarik kesimpulan

Pengujian keabsahan data pada penelitian ini dilakukan untuk menguji penelitian yang dimana dibuktikan kebenarannya serta dapat dilakukan untuk menguji data-data ilmiah yang diperoleh dalam penelitian ini. Adapun metode ataupun cara yang digunakan dalam memperoleh keabsahan data yaitu dengan cara triangulasi. Berbagai bentuk dalam pengecekan data yang diperoleh dari berbagai sumber untuk membuktikan kredibilitas diartikan dengan triangulasi, yang termasuk sebagai triangulasi sumber, dan teknik yang digunakan dalam membuktikan keabsahan data dalam penelitian ini (Sugiyono, 2016).

\section{Hasil dan Pembahasan}

Pelaku UMKM yang menerapkan fintech pada usahanya, menggunakan fintech seiring dengan perkembangan teknologi yang dimana pelaku UMKM harus menyesuaikan dengan perkembangan tersebut. Perkembangan teknologi yang terjadi serta kebiasaan masyarakat dalam hal cashless society dan hampir sebagian besar masyarakat membawa gadget yang menjadikan pelaku usaha harus menyesuaikan kebiasaan tersebut dengan menerapkan fintech pada usaha agar nantinya pelaku UMKM tidak terancam punah ataupun tertinggal. Penggunaan fintech yang diterapkan oleh pelaku UMKM ini, para pelaku UMKM mempertimbangkan beberapa alasan dalam penggunaan fintech.

Hal pertama yang menjadi alasan kunci dalam penerapan teknologi ini yaitu kemudahan. Penerapan fintech ini dapat memberikan kemudahan transaksi pada proses bisnisnya. Kemudahan yang diberikan diaanggap oleh pelaku UMKM sebagai percepatan dari bisnis mereka. Kemudahan tersebut dapat memberi kemudahan dalam melakukan transaksi, pencatatan transaksi yang masuk sehingga memudahkan mengetahui keadaan usaha saat ini, layanan transfer ke rekening, serta memeriksa stock barang mereka secara otomatis pada sistem. Hal ini sesuai dengan pemaparan dari Bapak Pradnyana yang merupakan pemilik dari Nuansa Kopi sebagai berikut : 
"Memudahkan pencatatannya dan transaksinya sih, misal pencatatan penjualan apa saja, misal dalam satu bulan berapa kali transaksi misal produk item yang populer secara otomatis jadi pasar lebih respon kesini".

Dampak yang dirasakan oleh pelaku UMKM dalam penerapan fintech pada usahanya, memberikan keuntungan bagi pelaku UMKM dan tidak hanya pelaku UMKM, pelangan juga diberikan kemudahan dalam hal ini. Berdasarkan penelitian yang dilakukan, pelaku UMKM menyebutkan bahwa dampak yang dirasakan yang paling utama yaitu memudahkan transaksi pembayaran dan memuaskan pelanggan serta memberikan kemudahan dalam pengaturan keuangan. Dengan adanya fintech, maka dapat dimudahkan dalam menginput pemasukan transaksi penjualan sehingga dapat memberikan efesiensi waktu bagi pelaku UMKM.

Dengan penerapan fintech, pelaku UMKM juga akan sangat dibantu dengan adanya fitur uang elektronik yang secara otomatis masuk ke rekening pelaku usaha yang dapat memudahkan penyetoran. Hal ini juga dipaparkan dalam wawancara dengan Maulana Hidayat, sebagai berikut:

"Ngga ribet menyesuaikan penjualannya saja, dia langusung terkomputerisasi berapa saja penjualan-penjualannya, besoknya dikirim dari pihak OVOnya. Nanti ketika sudah tercatat apa saja penjualannya nanti dikirim pihak OVO ke rekening saya".

Perkembangan teknologi yang terjadi mengharuskan pelaku UMKM untuk beradaptasi dengan teknologi. Penerapan teknologi diperlukan agar usaha yang dijalankan juga dapat mengikuti alur perkembangan teknologi oleh pemilik UMKM. Hal ini juga sesuai dengan argumen dari Desi Budiastini yang merupakan pemilik Azella Shop yaitu sebagai berikut:

\footnotetext{
"Kalau saya pribadi, kan sekarang teknologi sudah berkembang ya dan juga banyak masyarakat atau konsumen sudah serba oline sekarang bahkan dalam hal berbelanja, semua sudah belanja lewat online, termasuk saya sendiri lebih mudah dan praktis, sehingga secara tidak langsung juga dapat menarik pelanggan dan pelanggan senang jadinya kan penjualan saya meningkat dan saya juga melakukan transaksi dengan pemasok mudah dan aman. Itusih menurut saya".
}

Mengikuti perkembangan teknologi ataupun menyesuaikan teknologi yang terjadi saat ini menjadi salah satu alasan yang menjadikan pelaku UMKM menerapakan fintech pada usahanya. Dengan mengikuti perkembangan teknologi nantinya diharapkan teknologi ini diperlukan agar usaha dari pelaku UMKM yang dijalankan tidak ketinggalan akan perkembangan jaman.

Kebiasaan masyarakat yang bergantung pada teknologi, yang membuat masyarakat selalu bergantung pada gadget. Hampir setiap hari masyarakat tidak terlepas dari gadget, dan melakukan semua pekerjaan melalui gadget seperti kegiatan jual beli, bahkan melakukan pemesanan makanan melalui via aplikasi pada gadget. Kemudahan yang diberikan dalam bertransaksi ataupun memberikan kepraktisan ini yang menjadikan konsumen menggunakannya. Semakin berkembangnya teknologi, menjadikan semakin banyak konsumen menggunakan teknologi tersebut sehingga para pelaku usaha harus menyesuaikan diri dengan penggunaan teknologi tersebut. Teknologi keuangan seperti fintech akan memudahkan kepada para penggunanya. Kemudahan yang diberikan dari penggunaan fintech akan membuat pelaku UMKM menerapkannya agar menyesuaikan dengan kebiasan pelanggan.

Adapun penggunaan layanan fintech seperti pengatur keuangan yang diterapkan oleh beberapa pelaku UMKM yang diteliti akan memudahkan dalam melakukan perekaman transaksi keuangan sehingga pelaku UMKM dapat dengan mudah memahami dalam pengelolaan keuangan. Hal ini dipaparkan melalui wawancara dengan Bapak Pradnyana, sebagai berikut: 
"Dalam hal pencatatan untuk transaksi sudah gitu untuk stok barang secara otomatis, kadang kan kita buka nyatet jadi kita keluar hari ini apa aja. Report penjualtan minggu ini ada bulan ini juga ada, jadi kita bisa melihat kenaikan dan penurunan dari usaha kita selama ini".

Penggunaan fintech memberikan keuntungan bagi pelaku UMKM dalam pecatatan transaksi penjualan yang secara otomatis memberikan report penjualan dalam mingguan ataupun bulanan yang dapat memudahkan pelaku UMKM dalam melihat kinerja usahanya. Tentunya keuntungan dari penerapan fintech pada pelaku UMKM memberikan kemudahan dan mempercepat transaksi dengan pelanggan, sehingga transaksi yang terjadi lebih akurat.

Untuk pelaku UMKM yang hanya menerapkan fintech untuk pembayaran saja akan memberikan kemudahan bagi pelanggan yang melakukan transaksi melalui aplikasi payment gateway sehingga pelanggan tidak perlu susah untuk melakukan pembayaran. Hal ini sesuai dengan pemaparan dari Gede Udayana, sebagai berikut:

"Tentunya memudahkan pelanggan untuk melakukan pembayaran serta memudahkan pengelolaan keuangan dari mulai otomatis transaksi penjualan".

Dari semua narasumber yang diteliti, bahwa peran fintech memberikan dampak bagi usahanya. Dengan adanya peran fintech maka pelaku UMKM dapat dengan mudah memahami mengenai pengelolaan keuangan dengan kemudahan dalam mengetahui pemasukan dan pengeluaran yang terjadi pada transaksi yang terjadi. Hasil yang nyata diperoleh di lapangan dari alasan pelaku UMKM menerapkan fintech ini yaitu kemudahan, kepraktisan dan kecepatan dalam transaksi dan pencatatan. Hal lain dari penerapan fintech yaitu dapat memberi kemudahan kepada pelanggan. Kegiatan proses transaksi yang lebih efesien dan efektif yang menjadi alasan pelaku UMKM menerapkan fintech ini, perkembangan jaman juga memberikan tuntutan bahwa para pelaku usaha menerapkan fintech berbasis payment gateway ini.

\section{Simpulan dan Saran}

Berdasarkan hasil penelitian yang telah dibahas sebelumnya dapat disimpulkan beberapa pelaku UMKM yang menerapkan fintech berbasis payment gateway adalah para pelaku UMKM lebih memahami bahwa fintech ini hanya sekedar sebagai transaksi dengan pembayaran digital saja. Walaupun pada kenyataannya banyak peran fintech yang digunakan dalam bidang usaha untuk membantu kegiatan usaha UMKM dan dalam hal literasi keuangan, seperti pembiayaan dan pengaturan keuangan dan lain-lain. Pelaku UMKM mengatakan fintech ini digunakan untuk mempermudah transaksi dengan konsumen ataupun dengan distributor. Pada pelaku UMKM yang diteliti mengatakan bahwa fintech ini dapat membantu dalam pengelolaan keuangan seperti pencatatan pemasukan transaksi. Jadi disimpulkan bahwa peran fintech dapat membantu pelaku UMKM dalam meningkatkan literasi keuangan dengan membantu memahami mengenai pengelolaan keuangan yang dimudahkan dalam hal pencatatan pemasukan transaksi yang terjadi sehingga pelaku UMKM dapat dengan mudah mengelola kegiatan usahanya.

Berdasarkan pemaparan diatas maka dapat dihasilkan saran yang diperlukan jika melihat dari hasil penelitian bahwa masih adanya keterbatasan dalam penggunaan fintech pada UMKM di Kecamatan Buleleng yang dilihat masih dalam jumlah sedikit, agar nantinya dapat dijadikan pertimbangan untuk penelitian selanjutnya agar penelitian berikutnya menjadi lebih baik lagi. Diharapkan untuk peneliti selanjutnya, dapat menambah jumlah narasumber dengan ruang lingkup penelitian yang lebih luas sehingga hasil wawancara bisa lebih akurat. Bagi peneliti selanjutnya juga diharapkan dapat meneliti peran fintech yang lain dan tidak berfokus pada payment gateway. 


\section{Daftar Rujukan}

Astarina, S. (2018). 3 Keuntungan Menjadi Cashless Society, Sudah Merasakannya? KoinWorks. https://koinworks.com/blog/keuntungan-menjadi-cashless-society/

Astarina, S. (2019). 3 Keuntungan Menjadi Cashless Society, Sudah Merasakannya? KoinWorks. https://koinworks.com/blog/keuntungan-menjadi-cashless-society/

Dina, S. (2017). Pemerintah Mau 8 Juta UMKM Pakai Layanan Pembayaran Digital pada 2020. Kominfo.Go.ld. https://kominfo.go.id/content/detail/12092/pemerintah-mau-8-jutaumkm-pakai-layanan-pembayaran-digital-pada-2020/0/sorotan_media

Handinata, F. (2013). Definisi Dari Distruptive Technology Inovasi Teknologi. Scrib. https://www.scribd.com/doc/134909284/Definisi-Dari-Disruptive-Technology-AdalahInovasi-Teknologi

Martawardaya, B. (2016). Teknologi Disruptif dan Peluangnya. Medcom.ld. https://www.medcom.id/pilar/kolom/MkMYLawk-teknologi-disruptif-dan-peluangnya

Oloan, A. (2019). Pojok Literasi "Financial Technology Ramah Bagi Millenial" Edukasi Generasi Millenial Cara Bertransaksi Aman di Era Digital. Kompasiana. https://www.kompasiana.com/agus_oloan/5c95dc8f3ba7f74b9d698b85/pojok-literasifinancial-technology-ramah-bagi-millenial-edukasi-generasi-millenial-cara-bertransaksiaman-di-era-digital?page=all

Rahma, T. I. F. (2018). Persepsi Masyarakat Kota Medan Terhadap Penggunaan Financial Technology (Fintech). At-Tawassuth, III, 642-661.

Rif'ah, S. (2019). Fenomena Cashless Society di Era Milenial Dalam Perspektif Islam. AlMusthofa: Journal of Sharia Economics, 2, 5-10.

Siregar. (2016). Financial technology tren bisnis keuangan ke depan. Infobanknews. https://doi.org/https://doi.org/10.3929/ethz-b-000238666

Sugiyono. (2016). Metodologi Penelitian Kuantitatif, Kualitatif, dan R\&D. In CV Alfabeta. https://doi.org/https://doi.org/10.3929/ethz-b-000238666

Syarizka, D. (2019). Kontribusi UMKM terhadap PDB 2019 Doproyeksi Tumbuh 5\%. Ekonomi Bisnis.Com. https://ekonomi.bisnis.com/read/20190109/12/876943/kontribusiumkm-terhadap-pdb-2019-diproyeksi-tumbuh-5

Wibowo, R. (2017). Bisnis Di Era Disruptive Technology. Medium.Com. https://medium.com/@ryo.wbw/bisnis-di-era-disruptive-technology-7701a106c40a 